\title{
The Bending Moment Resistance of Corner Joints Reinforced with Glass Fiber Polymer
}

\author{
Mehmet Nuri YILDIRIM ${ }^{1}$, Önder TOR ${ }^{2 *}$, Abdurrahman KARAMAN ${ }^{3}$ \\ ${ }^{1}$ Karabük University, Department of Furniture and Decoration, Safranbolu Vacational School \\ Karabuk, TURKEY \\ ${ }^{2}$ Kastamonu University, Forest Industry Engineering, Kastamonu, TURKEY \\ ${ }^{3}$ Uşak University, Banaz Vocational High School, Uşak, TURKEY \\ *Corresponding author: ondertor@kastamonu.edu.tr
}

\begin{abstract}
Aim of study: This study aimed to determine the effects of glass fiber reinforced polymer (GFRP) and adhesive type on the diagonal compression and tensile strength in L-type corner joints connected by a wood biscuit.

Material and Methods: Medium density fiberboard coated with melamine plate (MDF-Lam), wood biscuit with a size number of 20 as the joining member, GFRP for strengthening purposes, and epoxy adhesive, polyvinyl acetate (PVAc-D4), polyurethane (PU-D4) as adhesives were used. The diagonal compression and tension tests were carried out under static load according to ASTM-D1037 standards.

Main results: Results indicated that using GFRP significantly increased the diagonal compression and tensile strength of L-type corner joints connected by a wood biscuit.

Highlights: It is recommended to use the combination of GFRP and epoxy adhesive to have better compression and tensile strength in the corner joints made of MDF-Lam.

Keywords: Adhesive, Tensile and compression strength, Epoxy, PVAc, PU, Wood biscuit

\section{Cam Elyaf Kumaş ile Desteklenmiş Köșe Birleștirmelerde Eğilme}

\section{Moment Direnci}

Öz

Çalı̧̧manın amacı: $\mathrm{Bu}$ çalışmada, ahşap bisküvilerle birleştirilen $\mathrm{L}$ tipi köşe birleştirmelerinin cam elyaf kumaş (GFRP) ile güçlendirilmesinin diyagonal çekme ve basma kuvvetine olan etkileri belirlenmesi amaçlanmıştır.

Materyal ve Yöntem: Deney örneklerin hazırlanmasında melamin plaka ile kaplanmış orta yoğunlukta lif levha (MDF-Lam), birleştirme elemanı olarak 20 numara ahşap bisküvi, güçlendirme amacıyla GFRP ve yapıştırıcı olarak polivinilasetat (PVAc-D4), poliüretan (PUD4) ve epoksi tutkalları kullanılmıştır. Deneyler ASTM-D1037 standartlarına göre statik yük altında gerçekleştirilmiştir.

Sonuçlar: L tipi köşe birleştirmelerin dış kısmında kullanılan GFRP'nin eğilme moment direncini önemli derecede artırmıştır.

Önemli Vurgular: Çekme ve basma kuvveti etkisindeki MDF-Lam dan yapılmış köşe birleştirmelerinde GFRP ve epoksi tutkalının beraber kullanılması önerilmektedir.

Anahtar kelimeler: Yapıştırıcı, Çekme ve basma direnci, Epoxy, PVAc, PU, Ahşap bisküvi 


\section{Introduction}

Furniture used in the residences and offices experience various forces directly or indirectly according to their places of use, which can result in the deformation of furniture, such as openings and crushing or cracking at any joining areas of furniture members. From this viewpoint, Smardzevski (2002) declared that the main reason for this kind of deformations were caused by the technological problems occurred during the gluing and assembling process. Some other factors such as type of wood and wood-base materials, moisture level, surface smoothness, adhesion direction (tangentialradial), density, and surface penetration along with adhesive type also affected the deformations as having mechanical stresses at the corner joints (Rowell, 2005; Karaman, Güven, Yeşil \& Yıldırım, 2017; Zhang and Eckelman, 2002). The destructive forces affecting corner joints can cause the furniture to undergo deformation over time.

Various joining members are used in corner joints of furniture members one of which is wood biscuit. The diagonal channels of wooden biscuit lamella, which were formed by compression during the production phase, were made to distribute the adhesive homogeneously on the surface of the biscuit lamella. In addition, the compressed state of the plates ensured that biscuit lamella was swelled by the moisture of the adhesive and was tightened in the furniture members (Çelikel, 2006). Demirel (2008) performed compression and tension tests in the corner joints of box type furniture joined with dowel, treenail, wood biscuit along with polyurethane, PVAc-D3, and PVAc-4 adhesives in MDF and PB. In the same study, it was reported that the biscuit joints performed better than the other joining members. In the case of comparing the adhesive types, the PVAc-D4 adhesive showed better performance under both compression and tension tests than the other adhesive types.

A considerable amount of research has also been conducted to improve the mechanical properties of structural wood and wood-based material using reinforcement materials. These reinforcement materials have been employed in the form of steel plates, aluminum plates, high strength steel wire, stressed steel plates, fiber reinforced polymers (FRP) such as carbon, aramid and glass fibers (Plevris and Triantafillou, 1992; Anshari, Kitamori, Jung, Komatsu \& Guan 2011; Nikolaos and Thanasis, 1992; Claisse and Davis, 1998). One of these studies reported the usage of fiber-reinforced polymers increased the strength, stiffness, and ductility characteristics of wood beams (Plevris \& Triantafillou, 1992). The size of the members in the wooden structure design depends on the appropriate joining details. In the studies carried out, it was stated that the high performance of joining members of the designed wooden structures was possible with increased strength against tensile forces, and this, in turn, was possible by strengthening these parts with fiber reinforced plastics (Akgül, 2007). Another study based on the reinforcement of timber beams reinforced with pultruded glass fiber reinforced polymers (GFRP) element. The results of this study indicated that there was significant improvement in flexural stiffness and capacity compared with unreinforced timber. Nikolaos \& Thanasis (1992) studied on the effect of mechanical properties of fir wood reinforced with carbon/epoxy fiberreinforced plastics (CFRP). The results showed that the mechanical properties of the fir wood were significantly increased with CFRP. The diagonal compression and tensile strength of L-type furniture corner joints supported by particleboard and GFRP were examined. It was stated that, according to experimental results, glass fiber reinforced material bore more diagonal compression and tensile force than the control specimens (Yerlikaya, 2012).

Claisse \& Davis (1998) studied on the high performance joining systems of wood. The specimens prepared by wrapping the joining areas of different length with glass fibers were subjected to tension test. They reported that these strengthened specimens exhibited very high performance during tension and unit deformation. Some important technological features, such as bending resistance, modulus of elasticity, tensile-shear resistance, shock resistance, density, thickness swelling, and water absorption, were determined for the glass fiber reinforced laminated veneer lumber. According to the test results, the intensity of glass fiber fabric reinforcement significantly increased the modulus of elasticity and shock 
resistance, and reduced the tensile-shear resistance, the percentages of thickness swelling and water absorption (Bal and Özyurt, 2015).

It was determined that the laminated wood material reinforced with PU-based adhesive and GFRP has 52\% better static bending resistance than the control specimens (Mistak, 2013). The mechanical properties of some laminated materials produced with GFRP were studied. According to the results of the tests, the modulus of elasticity and the bending strength of these reinforced specimens were reported to increase (Osmannezhad, Faezipour $\&$ Ebrahimi, 2014).

Therefore, the objectives of this study were to investigate the effects of GFRP and adhesive type on the compression and tension behavior of $\mathrm{L}$ type corner joints made of MDF-Lam.

\section{Materials and Methods}

\section{Materials and design of joint specimens}

The configuration of the L-shaped corner joint specimens is shown in Figure 1. In general, each specimen consisted of two principal structural members, an edge member (Member A) and a face member (Member B), jointed by a wood biscuit. All the specimens were constructed of $18-\mathrm{mm}-$ thick MDF-Lam used extensively in furniture industry. The dimensions of members were $132 \mathrm{~mm}$ in length by $100 \mathrm{~mm}$ in width for Member A and $150 \mathrm{~mm}$ in length by $100 \mathrm{~mm}$ in width for Member B. A hole for the wood biscuit was drilled into the Member B at a point midway across $100 \mathrm{~mm}$ joining face at a point $9 \mathrm{~mm}$ from its edge, perpendicular to the face. A corresponding hole was drilled in the center of one edge of the Member A perpendicular to the face of that edge. The holes in the members and sides of the wood biscuit were cleaned with compressed air to have better bonding before applying the adhesives. Solid wood biscuits (No.20) made of oriental beech (Fagus orientalis) were used in this study. The dimensions of the biscuit were $60 \mathrm{~mm}$ in length by $24 \mathrm{~mm}$ in width by $4 \mathrm{~mm}$ in thickness.

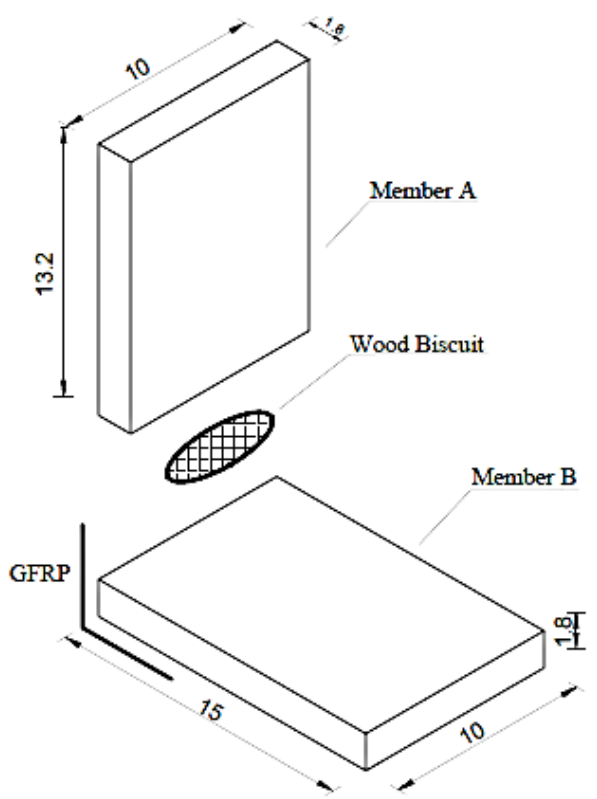

Figure 1. General configuration of the test specimen $(\mathrm{cm})$.

The specimens were separated into two groups in one half of which the specimens were reinforced with GFRP with a density of $300 \mathrm{~g} / \mathrm{m}^{2}$ with the size of $15 \times 10 \mathrm{~cm}$ used as strengthening material (Figure 2). There was no reinforcement material used in the remained half of the specimens which recorded as control specimens. In both groups, three different types of adhesives (PVAc-D4, PU-D4 and epoxy adhesive) were used to assemble the members. The adhesives were applied in the walls of the holes and the sides of the wood biscuit prior to insertion of the wood biscuits. The wood biscuits were firstly inserted in the Member B and then Member A. All specimens were cold pressed under a pressure of $0.2 \mathrm{~N} / \mathrm{mm}^{2}$. The assembled specimens were kept at $20 \pm$ $2{ }^{\circ} \mathrm{C}$ and $65 \pm 5 \%$ relative humidity until the test time. 


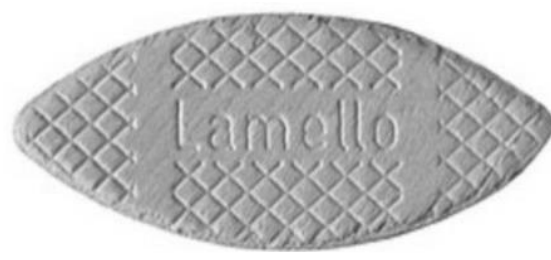

a)

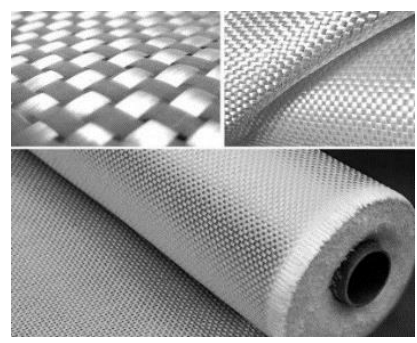

b)

Figure 2. a) Wood biscuit, b) Glass Fiber Fabric (GFRP)

\section{Experimental design}

A complete two-factorial experiment was conducted to evaluate effects of corner joint type and adhesive type on compression and tension strength of the joint. Ten replications per combination were tested so that a total of 120 specimens were subjected to compression and tension loading.

\section{Method of loading and testing}

The maximum compression and tensile strength of the test specimens at fracture point were recorded in terms of Newton $(\mathrm{N})$. The ultimate load resistance of the joints was defined as load resistance at failure. In compression and tension tests (Figure 3-a and $b$ ), the values of the ultimate load resistance were converted to corresponding bending moment resistance values by means of the equations below (Zhang and Eckelman 1993);

Equation 1. The ultimate bending moment resistance in compression $(N \cdot m)$

$$
\mathrm{M}_{\mathrm{c}}=0.080601 \times \mathrm{F}_{\operatorname{maxc}}
$$

Equation 2. The ultimate bending moment resistance in tension $(N \cdot m)$

$$
\mathrm{M}_{\mathrm{t}}=0.09334 \times 0.5 \mathrm{~F}_{\operatorname{maxb}}
$$

Where:

$M_{c}$ and $M_{t}=$ the ultimate bending moment resistance in compression and tension, respectively $(\mathrm{N} \cdot \mathrm{m})$

$\mathrm{F}_{\operatorname{maxc}}$ and $\mathrm{F}_{\text {maxb }}=$ applied for compression and tension respectively $(\mathrm{N})$

All test joints were performed on a Universal Testing Machine. For the compression test, specimens were placed between the machine head and the tabletop of the testing machine and loaded to failure (Figure 4-a). In the case of tension test, both members of the joint specimens were placed on the rollers to move freely so that the joint was forced to failure (Figure 4-b). The loading speed was set to $10 \mathrm{~mm} / \mathrm{min}$.

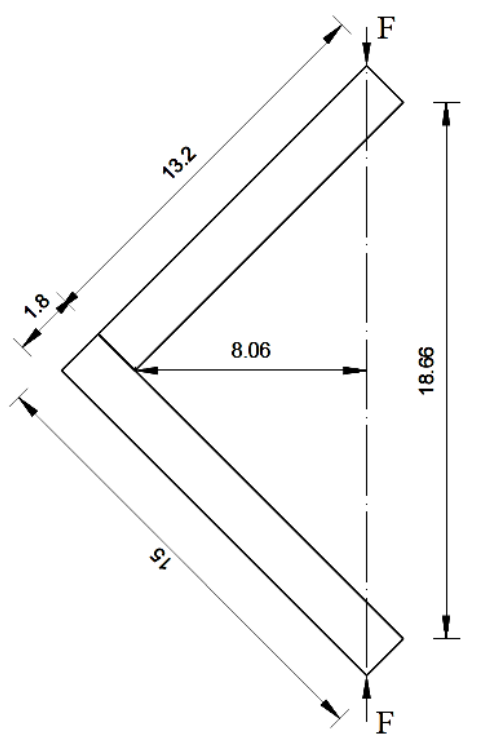

a)

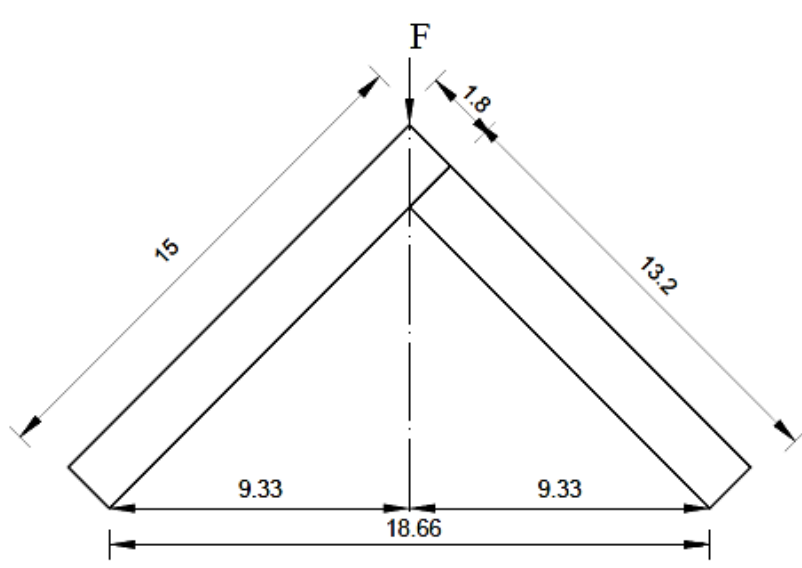

b)

Figure 3. Cross sectional measurements $(\mathrm{cm})$ and loading form in (a) diagonal compression test, (b) diagonal tension test 


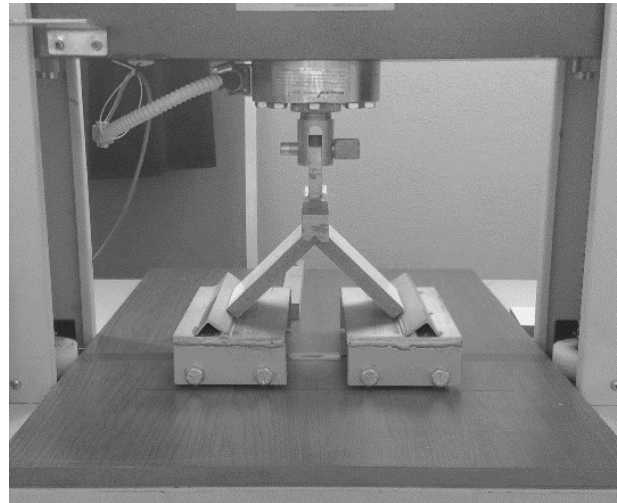

a)

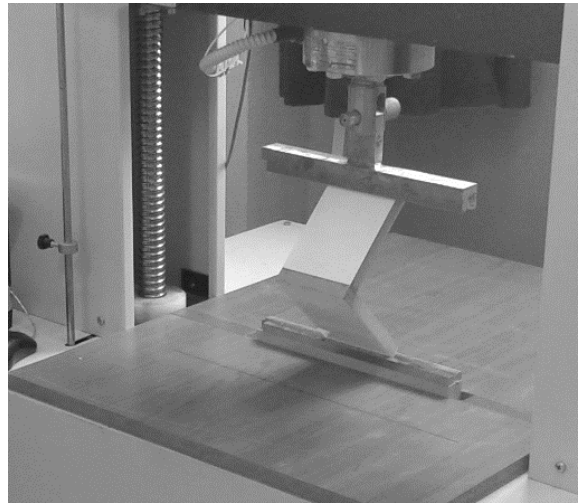

b)

Figure 4. (a) diagonal compression test; (b) diagonal tension test

\section{Statistical analysis}

General linear model (GLM) procedure for a two-factor analysis (ANOVA) was performed to analyze two main effects and their interactions on means of bending moment in compression and tension strength in the joint. This procedure was followed by the protected least significant difference (LSD) multiple comparison procedure to compare means based on the significance of the interaction between the factors, otherwise significance of main effects. All statistical analyses were performed at the $5 \%$ significance level.

\section{Results and Discussion}

Table 1 summarizes mean bending moment resistance for compression and tension tests of the L-type corner joint with wood biscuit inserted within each combination of adhesive and corner joint type.

\section{Mean comparisons for compression and tension tests}

In general, the results indicated that the joint loaded in tension had almost greater resistance than the corresponding ones in compression with the ratio from 1.73 to 2.07 for the control joints and from 1.68 to 1.95 for the joints reinforced with the GFRP. ANOVA results for both compression and tension test showed that the two-way interactions between corner joint type and adhesive type were statistically significant with a $\mathrm{p}$ value of less than 0.0001 . The coefficient determination values, $r^{2}$, were 0.95 and 0.97 for compression and tension tests, respectively. The results were based on a one-way classification created with 12 treatment combinations in total with respect to the two-way interaction and mean comparisons among these combinations using LSD value of 4.26 and $6.25 \mathrm{~N} \cdot \mathrm{m}$ compression and tension tests.

Table 1. Mean bending moment resistance $(\mathrm{N} \cdot \mathrm{m})$ for compression and tension tests of the Ltype corner joint with wood biscuit inserted within each combination of adhesive and corner joint type.

\begin{tabular}{ccccc}
\hline \multirow{2}{*}{$\begin{array}{c}\text { Corner joint } \\
\text { type }\end{array}$} & Adhesive & \multicolumn{2}{c}{$\begin{array}{c}\text { Average Bending Moment } \\
\text { Resistance }\end{array}$} & \multirow{2}{*}{$\begin{array}{c}\text { Ratio } \\
\text { T/C }\end{array}$} \\
\cline { 2 - 4 } & & Compression (C) & Tension (T) & \\
\hline \multirow{4}{*}{ Control joint } & Polyurethane Adhesive (PU-D4) & $27.79(12)^{*}$ & $50.13(8)$ & 1.80 \\
& $\begin{array}{c}\text { Polyvinyl acetate Adhesive (PVAc- } \\
\text { D4) }\end{array}$ & $22.18(15)$ & $38.44(14)$ & 1.73 \\
& Epoxy Adhesive & $45.72(6)$ & $94.68(9)$ & 2.07 \\
\hline \multirow{3}{*}{$\begin{array}{c}\text { Joint with } \\
\text { GFRP }\end{array}$} & $\begin{array}{c}\text { Polyurethane Adhesive (PU-D4) } \\
\text { Polyvinyl acetate Adhesive (PVAc- }\end{array}$ & $48.84(15)$ & $82.29(7)$ & 1.68 \\
& $\begin{array}{c}\text { D4) } \\
\text { Epoxy Adhesive }\end{array}$ & $82.29(14)$ & $70.66(12)$ & 1.67 \\
\hline
\end{tabular}

* Values in parentheses are coefficients of variance (\%) 


\section{Corner joint effects}

In general, mean bending moment resistance for both compression and tension loads in the corner joint reinforced with
GFRP was statistically higher than the ones in joint with no reinforcement material used in the connection. This trend obtained in all adhesive

types.

Table 2. Mean bending moment resistance $(\mathrm{N} \cdot \mathrm{m})$ for compression test for corner joint within each adhesive.

\begin{tabular}{ccc}
\hline \multirow{2}{*}{ Adhesive } & \multicolumn{2}{c}{ Corner joint } \\
\cline { 2 - 3 } & Control joint & Joint with GFRP \\
\hline PU-D4 & $(27.79) \mathrm{B}$ & $(48.84) \mathrm{A}^{*}$ \\
PVAc-D4 & $(22.18) \mathrm{B}$ & $(42.29) \mathrm{A}$ \\
Epoxy Adhesive & $(45.72) \mathrm{B}$ & $(82.05) \mathrm{A}$ \\
\hline
\end{tabular}

*Means in each row not followed by a common letter are significantly different from one another.

Table 3. Mean bending moment resistance $(\mathrm{N} \cdot \mathrm{m})$ for tension test for corner joint within each adhesive.

\begin{tabular}{ccc}
\hline \multirow{2}{*}{ Adhesive } & \multicolumn{2}{c}{ Corner joint } \\
\cline { 2 - 3 } & Control joint & Joint with GFRP \\
\hline PU-D4 & $(50.13) \mathrm{B}$ & $(82.29) \mathrm{A}^{*}$ \\
PVAc-D4 & $(38.44) \mathrm{B}$ & $(70.66) \mathrm{A}$ \\
Epoxy Adhesive & $(94.68) \mathrm{B}$ & $(160.01) \mathrm{A}$ \\
\hline
\end{tabular}

*Means in each row not followed by a common letter are significantly different from one another.

\section{Adhesive effects}

In general, the epoxy adhesive applied corner joints had higher mean bending moment resistance than the PU-D4 and PVAc-D4. When comparing the PU-D4 and PVAc-D4, the mean bending moment resistance was lower in PVAc-D4 than the ones in PU-D4. This can be explained by the difference of adhesives' internal fiber bond strength (cohesive strength). It can be argued that the high performance of the epoxy adhesive is due to the fact that, at the molecular level, it rapidly penetrates into the outer surface and hole of the wooden biscuit, adheres to surface voids, and forms a strong adhesion surface in these regions.

Table 4. Mean bending moment resistance $(\mathrm{N} \cdot \mathrm{m})$ for compression test for adhesive within each corner joint.

\begin{tabular}{cccc}
\hline \multirow{2}{*}{ Corner joint } & \multicolumn{3}{c}{ Adhesive } \\
\cline { 2 - 4 } & PU-D4 & PVAc-D4 & Epoxy Adhesive \\
\hline Control joint & $(27.79) \mathrm{B}$ & $(22.18) \mathrm{C}$ & $(45.72) \mathrm{A}^{*}$ \\
Joint with GFRP & $(48.84) \mathrm{B}$ & $(42.29) \mathrm{C}$ & $(82.05) \mathrm{A}$ \\
\hline
\end{tabular}

*Means in each row not followed by a common letter are significantly different from one another.

Table 5. Mean bending moment resistance $(\mathrm{N} \cdot \mathrm{m})$ for tension test for adhesive within each corner joint.

\begin{tabular}{cccc}
\hline \multirow{2}{*}{ Corner joint } & \multicolumn{3}{c}{ Adhesive } \\
\cline { 2 - 4 } & PU-D4 & PVAc-D4 & Epoxy Adhesive \\
\hline Control joint & $(50.13) \mathrm{B}$ & $(38.44) \mathrm{C}$ & $(94.68) \mathrm{A}^{*}$ \\
Joint with GFRP & $(82.29) \mathrm{B}$ & $(70.66) \mathrm{C}$ & $(160.01) \mathrm{A}$ \\
\hline
\end{tabular}

*Means in each row not followed by a common letter are significantly different from one another.

The higher performance of the epoxy adhesive can be attributed to the increased elasticity of the epoxy adhesive, which enhances the molecular bonding of the wood biscuit surface and the biscuit hole surfaces to the adhesive. The adhesive penetrates into the surface cavities deeper and faster than other adhesives, and a strong specific adhesion of the adhesive and the material molecules in these regions leads to a stronger mechanical bonding surface. 


\section{Conclusions}

In this study, the diagonal tensile and compression force values of "L" type corner joints made of medium density fiberboard (MDF-Lam) coated with melamine plate and reinforced with GFRP were examined based on two factors. These factors were joint type (control joint and joint with reinforced GFRP) and adhesive types (PVAc-D4, PUD4 and epoxy adhesive). GFRP reinforced specimens were found to perform better than the specimens that were not reinforced with GFRP in compression and tension tests. The results also indicated that using epoxy adhesive in the wood biscuit joints with GFRP on the out-corner showed higher performance than the corresponding ones with PU-D4 and PVAc-D4 in compression and tension tests.

\section{References}

Akgül, T. (2007). Strengthening of wood and joints with fiber-reinforced polymers. Master Thesis Sakarya University Institute of Natural Sciences Sakarya, 13-42.

Anshari, B., Kitamori, A., Jung, K., Komatsu, K. \& Guan, Z. (2011). Experimental study on structural behavior of glulam beams prestressed by compressed wood. Wood Research Journal, 2(1), 54-61.

Bal, C. \& Özyurt, H. (2015). Some technological properties OF laminated veneer lumber reinforced WITH woven glass fiber. Kahramanmaras Sutcu Imam University. Journal of Engineering Sciences, 18(1), 2015, 9-16.

Claisse, P. A. \& Davis, T. J. (1998). High performance jointing systems for timber. Construction and Building Materials. 12, 415425.

Çelikel, Ü. (2006). The Effects of wood louse tongue (biscuit joint) on the strength of corner joints in case furniture. Master Thesis, Gazi University Institute of Natural Sciences, Ankara, 48.

Demirel, E. (2008). The effects of different types of glue and material used on the corner joining of box type furniture constructions. Master Thesis, Zonguldak Karaelmas University, Institute of Science, Bartin.

Karaman, A., Güven, Ş., Yeşil, H. \& Yıldırım, M. N., (2017). Determination of the diagonal tensile force and pressure force in furniture corner assemblies prepared by using different glues. Suleyman Demirel University, Journal of Technical Sciences, 7(2), 26-36.

Mistak, O. (2013). Determination of mechanical properties of lamina wood materials obtained with scots pine and different fiber (FRP) fabrics. Master Thesis, Karabuk University Institute of Science, Karabuk, 49-66.

Nikolaos, P. \& Thanasis, T. (1992). FRPreinforced wood as structural material. Journal of Materials in Civil Engineering 4(3), 300-317.

Osmannezhad, S., Faezipour, M. \& Ebrahimi, G. (2014). Effects of GFRP on bending strength of glulam made of poplar (Populus deltoids) and beech (Fagus orientalis). Construction and Building Materials, 51, 34-39.

Plevris, N. \& Triantafillou, T. C. (1992). FRPreinforced wood as structural material. Journal of Materials in Civil Engineering. ASCE, 4(3), 300-317.

Rowell, R. (2005). Handbook of wood chemistry and wood composites. CRC Press, ISBN 08493-1588-3, New York.

Smardzevski, J. (2002). Technological heterogeneity of adhesive bonds in wood joints. Wood Science and Technology. 36(3), 213-227.

Yerlikaya, N. (2012). Effects of glass-fiber composite, dowel, and minifix fasteners on the failure load of corner joints in particleboard case-type furniture. Materials and Design, 39, 63-71.

Zhang, J. L., Erdil, Y. Z. \& Eckelman, C. A. (2002). Lateral Holding Strength of Dowel Joints Constructed of Plywood and Oriented Strandboard. Forest Product Journal, 52(7/8), 83-89.

Zhang, J. \& Eckelman, C. A. (1993). The bending moment resistance of single-dowel corner joints in case construction. Forest Product Journal, 43(6), 19-24. 